\title{
$\mathrm{AlN}$ 입자 함유 폴리머 후막을 $\mathrm{Al}$ 기판에 형성한 2층 층상재료의 두께 방향에 대한 열전도 특성 \\ ${ }^{1}{ }^{ㅂ ㅜ ㅅ ㅏ ㄴ ㄷ ㅐ ㅎ ㅏ ㄱ ㄱ ㅛ ~ ㅈ ㅐ ㄹ ㅛ ㄱ ㅗ ㅇ ㅎ ㅏ ㄱ ㅂ ㅜ ~}$ \\ ${ }^{2}$ 부산대학교 수송기기하이테크소재부품전공 \\ 한국기계연구원 부설 재료연구소 \\ ${ }^{4}$ 가야대학교 안경광학과
}

\section{Thermal Properties of Two-Layered Materials Composed of Polymer Layer Embedded with AIN Particles on Al Substrate along the Thickness Direction}

\author{
Jong-Gu Kim ${ }^{1}$, Jae-Hoon $\mathrm{Ju}^{2}$, Byung-Dong Hahn ${ }^{3}$, Sang-Hee Park ${ }^{4}$, and Young-Rae Cho ${ }^{1, *}$ \\ ${ }^{l}$ Division of Materials Science and Engineering, Pusan National University, Busan 46287, Republic of Korea \\ ${ }^{2}$ Department of Advanced Materials and Parts of Transportation Systems, Pusan National University, Busan 46287, \\ Republic of Korea \\ ${ }^{3}$ Korea Institute of Materials Science, Changwon 51508, Republic of Korea \\ ${ }^{4}$ Department of Ophthalmic Optics, Kaya University, Gyeongnam 50830, Republic of Korea
}

\begin{abstract}
The thermal properties of two-layered materials composed of a polymer layer embedded with dielectric AlN particles (AlN composite) coated on top of an aluminum (Al) substrate were investigated by light flash analysis (LFA). The thermal conductivity of the specimens was measured as a function of the AlN composite volume fraction along the thickness direction. By observing the microstructure of the two-layered materials in cross section, we found a tremendous number of randomly distributed pores and boundaries in the AlN composite. Compared to the conventional thermal resistor model, the thermal conductivity values of the specimens measured by LFA were significantly different. When the solid solution model was applied in this study, however, the measured thermal conductivity of the specimens showed good agreement with the values from the solid solution model. The good agreement in thermal conductivities for the specimens was due to the presence of many randomly distributed pores and boundaries in the AlN composite.
\end{abstract}

(Received October 6, 2016; Accepted December 10, 2016)

Keywords: thermal conductivity, layered materials, thick film, thickness direction, thermal property

\section{1. 서 론}

전자소자의 고집적화 추세가 빠르게 진행됨에 따라 단위 면적당 발생하는 열의 증가는 전자소자의 특성에 심각한 영 향을 미친다 [1-3]. 발광다이오드(LED)의 경우, 반도체소자 의 접합부에서 발생하는 과열로 인해 소자의 발광효율이 급 격하게 감소된다. 컴퓨터의 중앙처리장치(CPU)와 전력반도 체 소자에서도 소형화와 고성능화 추세로 인해 생긴 열을 효 과적으로 방출시키는 기술이 요구된다. 전자소자에서 생기 는 발열의 원인은 작은 체적의 반도체 칩에 많은 전류가 흐르

*Corresponding Author: Young-Rae Cho

[Tel: +82-51-510-2389, E-mail: yescho@pusan.ac.kr]

Copyright (c) The Korean Institute of Metals and Materials
기 때문이다. 칩에서 발생한 열을 효과적으로 방출시키는 방 법의 하나로 고성능 리드프레임이 사용되기도 하지만, 발열 문제가 심각한 경우 히트 싱크(heat sink)나 히트 파이프(heat pipe)를 사용하기도 한다 [1,2].

고출력 $\mathrm{LED}$ 와 고발열 전자소자에 사용되는 방열모듈은 대부분 다층 층상구조를 갖는다. 일반적으로 전자소자는 절 연기판(insulating substrate)에 탑재되며, 절연기판은 열계면 재료(thermal interface material)를 사용해 열전도성이 우수 한 금속재료 방열판에 부착된다. 절연기판은 열전도도가 높 을수록 바람직하며, 탄소화합물 혹은 질소화합물이 첨가된 후막(thick film) 형태의 복합재료(composite)가 사용된다 [3-6]. 열계면재료로는 열전도 특성과 본딩 특성이 우수한 고 


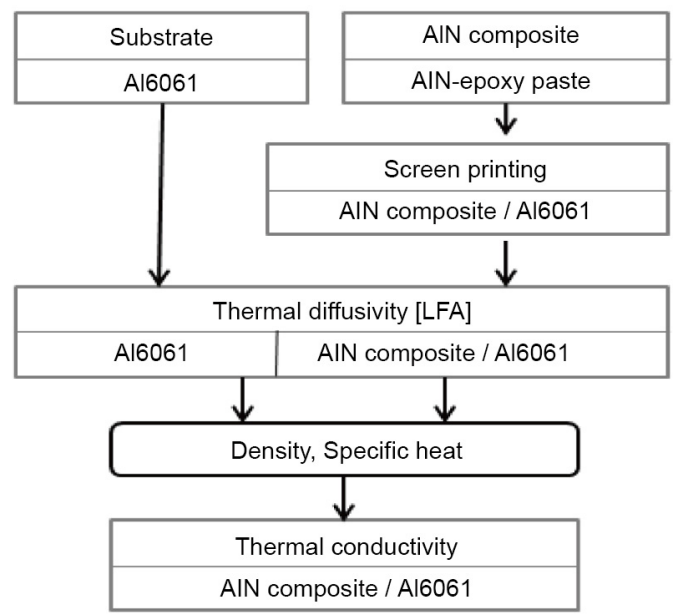

Fig. 1. Schematic diagram of experimental procedure.

분자 재료가 사용된다. 방열판 재료로는 열전도 특성과 기계 가공성이 우수한 알루미늄(Al) 합금을 주로 사용한다. 방열 은 방열모듈의 두께 방향으로 대부분 일어나기 때문에 두께 방향에 대한 열전도 특성을 이해하는 것이 필수적이다. 따라 서, 우수한 다층구조를 갖는 방열모듈에 대한 두께 방향으로 열전도 특성을 깊이 있게 연구해야 한다 $[7,8]$. 현재까지 수행 된 대부분의 연구는 단층구조를 갖는 재료에 대한 것이며, 다 층구조를 갖는 방열모듈의 두께 방향으로 열전도에 대한 연 구는 많지 않다 $[9,10]$. 특히, 판상의 기판에 형성시킨 유전체 (dielectric material) 후막의 열전도 특성을 이해하는 것은 중 요하지만, 두께가 $200 \mu \mathrm{m}$ 이하로 얇은 후막에 대해 두께방향 으로 열전도 특성에 대한 연구는 거의 없다 [11].

본 연구는 $\mathrm{LED}$ 용 다층구조 방열모듈에서 두께 방향으로 열전도 특성을 이해하기 위한 기초 연구로, 금속기판에 유전 체 후막을 코팅시킨 2층 층상재료(two-layered material) 시편 을 제작하여 두께 방향으로 열전도 특성을 연구하였다. 금속 기판으로는 열전도 특성이 우수한 알루미늄을 선택하였으 며, 유전체 후막으로는 전기적 부도체로 열전도 특성이 뛰어 난 질화알루미늄(AlN) 입자가 함유된 에폭시수지(epoxy resin)를 스크린 인쇄해서 만든 AlN 복합재료(AlN composite) 후막을 사용하였다. 금속기판과 복합재료 후막 및 2 층 층상 재료 시편에 대해 각각 섬광법(light flash analysis, LFA)을 사용해 두께 방향으로 열확산계수를 측정하였다. 유전체인 $\mathrm{AlN}$ 복합재료 후막의 두께를 실험변수로 제조한 2층 층상재 료의 열전도 특성을 측정하고 이론적으로 고찰함으로써, 2 층 층상재료 시편에 대해 두께 방향으로 열전도 특성을 파악하 고자 하였다.

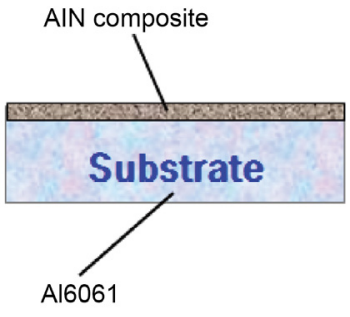

(a)

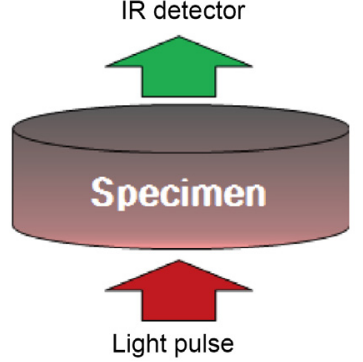

(b)
Fig. 2. Schematic diagram of specimen and heat flow: (a) AlN composite coated on the Al6061 substrate and (b) configuration of specimen in light flash analysis(LFA).

\section{2. 실험 방법}

그림 1은 판상의 $\mathrm{Al}$ 기판에 $\mathrm{AlN}$ 함유 폴리머(AlN 복합재 료) 후막을 코팅한 2 층 층상재료의 제조와 시편의 열전도 특 성 평가에 사용된 실험의 주요 공정을 도식적으로 나타낸 것 이다. $\mathrm{Al}$ 기판으로는 Al6061합금이 사용되었으며, $\mathrm{AlN}$ 복합 재료 후막은 AlN함유 폴리머를 사용해서 제조하였다. $\mathrm{Al}$ 기 판과 $\mathrm{AlN}$ 복합재료 및 2층 층상재료 시편에 각각에 대해 열 확산계수를 측정하고, 밀도 및 비열을 사용해서 각각의 열전 도도를 구했다.

그림 2는 본 연구에 사용된 시편의 단면형상과 열확산계수 의 측정원리를 간략하게 나타낸 개념도이다. 그림 2(a)에서 보듯이, 2층 층상재료 시편의 단면구조는 A16061 기판에 유 전체인 AlN 복합재료 후막을 형성시킨 2층 단면구조의 층상 구조를 갖는다. 기판은 두께가 $2.02 \mathrm{~mm}$ 이고, 면적이 $8 \times 8$ $\mathrm{mm}^{2}$ 인 판상이다. Al6061을 기판으로 사용한 이유는 가공성 과 열전도 특성이 우수해 히트 싱크(heat sink) 재료로 적당하 기 때문이다.

$\mathrm{AlN}$ 복합재료 후막은 (주)IMD의 제품코드 AN-2501인 AlN 함유 페이스트(paste)를 사용해 스크린 인쇄한 후 $150{ }^{\circ} \mathrm{C}$ 에서 30 분 동안 소성시켜 제조하였다. $\mathrm{AlN}$ 함유 페이스트는 $\mathrm{BPF}$ (bisphenol f epoxy resin) 계통이며, 주요 성분은 무게비 로 AlN filler가 $65 \%$, 에폭시 수지(epoxy resin)가 $28 \%$ 이며, 경화제가 7\%였다. Filler로 사용된 $\mathrm{AlN}$ 입자는 열전도도가 높 으면서, 전기적 부도체이기 때문에 전자소자용 부품에서 절 연 및 열 방출 소재로 사용된다. AlN 복합재료 후막의 두께는 $163 \mu \mathrm{m}$ 까지 변화시켰으며, 스크린인쇄의 횟수를 변화시켜 두께를 조절하였다.

그림 2(b)는 시편의 두께 방향으로 열확산계수를 측정하는 


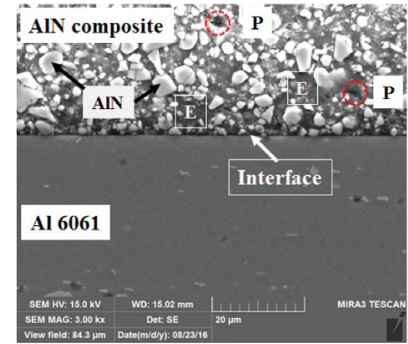

(a)

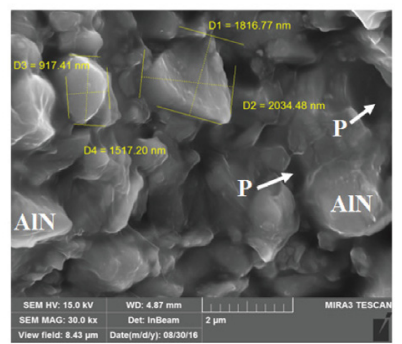

(b)
Fig. 3. SEM images of specimen: (a) cross-sectional view of AIN composite coated on the Al6061 substrate and (b) enlarged top view for AlN composite. [P: pore, E: epoxy resin].

원리를 도식적으로 나타낸다. 시편의 열확산계수는 Netzsch 사의 light flash analysis(모델명: LFA 447 NanoFlash)를 사 용해 상온에서 측정하였다 [3]. 열확산계수의 측정시 펄스형 빛(light pulse)의 흡수를 돕기 위해, 콜로이드 상태의 흑연입 자를 시편의 양쪽면에 분사 코팅했다. 열주입은 시편의 아랫 면에 펄스의 길이가 $0.4 \mathrm{~ms}$ 인 Xenon-flash lamp를 조사해 수 행하였으며, 시편의 윗면에 비접촉식 적외선 온도센서(IR detector)를 사용해 시간에 따른 온도증가 모드의 그래프에서 열확산계수를 구했다. 본 연구에서, 열확산계수를 사용한 시 편의 열전도도는 아래의 식으로 계산하였다 [12,13].

$$
\mathrm{k}=\alpha \rho \mathrm{C}_{\mathrm{p}}
$$

식 (1)에서 $\mathrm{k}(\mathrm{W} / \mathrm{m} \cdot \mathrm{K})$ 는 열전도도, $\alpha\left(\mathrm{mm}^{2} / \mathrm{s}\right)$ 는 열확산계 수, $\rho\left(\mathrm{g} / \mathrm{cm}^{3}\right)$ 는 밀도, $\mathrm{C}_{\mathrm{p}}(\mathrm{J} / \mathrm{kg} \cdot \mathrm{K})$ 는 비열을 나타낸다. 밀도는 아르키메데스의 수중부유법을 사용해 측정하였으며, 비열은 시차주사열량계(differential scanning calorimetry, DSC)를 사용해 측정했다. 2 층 층상재료 시편에 대한 밀도와 비열은 $\mathrm{Al}$ 기판과 유전체 후막에서 측정한 값을 사용해 부피비율을 고려한 혼합법칙(rule of mixture)을 적용시켜 구했다 [3].

또한, 식 (1)을 사용해 계산한 2층 층상재료 시편에 대한 열전도도 값의 검증을 위해 현재까지 알려진 몇 가지의 열전 도도 예측모델을 적용시켜 결과를 비교하였다. Krishnaiah 등은 다층 층상재료의 열전도도를 전기전도 이론과 결부시 켜, 2 층 층상재료가 가질 수 있는 열전도도의 최대값과 최소 값은 아래와 같은 수식으로 나타냈다 [13]. 최대값은 열흐름 의 방향이 층상재료의 배열과 나란한 경우로, 마치 전기저항 의 병렬모델(parallel model)과 비슷한 이론으로 표시된다.

$\mathrm{kcomp}(\mathrm{P})=\mathrm{km} \mathrm{fm}+\mathrm{kL} \mathrm{fL}_{\mathrm{L}}$
Table 1. Thermal conductivity related data for Al6161, AlN composite and epoxy resin.

\begin{tabular}{ccccc}
\hline Material & $\begin{array}{c}\text { Density } \\
{\left[\mathrm{g} / \mathrm{cm}^{3}\right]}\end{array}$ & $\begin{array}{c}\text { Specific } \\
\text { heat } \\
{[\mathrm{J} / \mathrm{kg} \cdot \mathrm{K}]}\end{array}$ & $\begin{array}{c}\text { Thermal } \\
\text { diffusivity } \\
{\left[\mathrm{mm}^{2} / \mathrm{s}\right]}\end{array}$ & $\begin{array}{c}\text { Thermal } \\
\text { conductivity } \\
{[\mathrm{W} / \mathrm{m} \cdot \mathrm{K}]}\end{array}$ \\
\hline Al6061 & 2.70 & 896 & 65.44 & 158.3 \\
\hline $\begin{array}{c}\text { AlN } \\
\text { composite }\end{array}$ & 2.21 & 754 & 0.36 & 0.60 \\
\hline Epoxy resin & 1.18 & 1150 & 0.15 & 0.20 \\
\hline
\end{tabular}

반면, 최소값은 열흐름의 방향이 2층 층상재료의 배열과 수직인 두께 방향으로 열흐름이 생기는 경우로, 마치 전기저 항의 직렬모델(series model)과 비슷한 이론으로 아래와 같이 표시된다.

$$
\mathrm{kcomp}(\mathrm{S})=[\mathrm{km} \mathrm{kL}] /[\mathrm{km} \mathrm{fL}+\mathrm{kL} f \mathrm{~m}]
$$

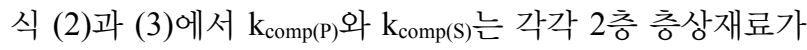
가질 수 있는 열전도도의 최대값과 최소값을 나타낸다. $\mathrm{k}_{\mathrm{m}}$ 과 $\mathrm{f}_{\mathrm{m}}$ 은 2층 층상재료에서 모재(matrix)인 $\mathrm{Al}$ 기판의 열전도도 와 부피분율을 나타내며, $\mathrm{k}_{\mathrm{L}}$ 과 $\mathrm{f}_{\mathrm{L}}$ 은 $\mathrm{AlN}$ 복합재료 후막의 열 전도도와 부피분율을 나타낸다.

또한, 미세조직과 열전도 특성의 관계를 알아보기 위해, 광 학현미경(optical microscopy, $\mathrm{OM}$ )과 주사전자현미경 (scanning electron microscopy, SEM)을 사용해 AlN함유 폴 리머 후막과 $\mathrm{Al} 6061$ 기판 및 2층 층상재료 시편에 대해 미세 조직을 관찰하였다.

\section{3. 실험 결과}

그림 3(a)는 $\mathrm{Al} 6061$ 기판에 $\mathrm{AlN}$ 복합재료 후막이 형성된 2 층 단면구조 시편을 경면 가공한 2층 층상재료에 대한 $\mathrm{SEM}$ 사진이고, 그림 $3(\mathrm{~b})$ 는 $\mathrm{AlN}$ 복합재료 후막을 확대시켜 관찰 한 SEM 미세조직이다. 그림 3(a)에서 보듯이, AlN 복합재료 후막과 $\mathrm{Al}$ 기판의 경계부분에 계면(interface)이 관찰되며, 연 속상의 에폭시수지(E로 표시)에 다양한 크기의 $\mathrm{AlN}$ 입자가 분산되어 존재한다. 그림 3에서 알 수 있듯이, $\mathrm{AlN}$ 입자의 지 름은 대략 0.1 2.5 $\mu \mathrm{m}$ 으로 관찰되며, $\mathrm{AlN}$ 입자와 에폭시수지 의 계면 주변에서는 다양한 크기의 기공(pore, $\mathrm{P}$ 로 표시)이 관찰된다. 그림 3(b)에서, $\mathrm{AlN}$ 입자의 주변에서 관찰되는 수 많은 기공들의 존재는 유전체에서 주요 열전달 매체인 포논 의 진행을 방해하기 때문에 열전도도가 낮아진다 [14]. 또한, $\mathrm{AlN}$ 복합재료 후막에 존재하는 수많은 $\mathrm{AlN}$ 입자와 에폭시수 
Table 2. Thickness and physical properties of each specimen which has different volume fractions of AlN composite.

\begin{tabular}{|c|c|c|c|c|c|c|}
\hline $\begin{array}{l}\text { Thickness of AlN } \\
\text { composite }[\mu \mathrm{m}]\end{array}$ & $\begin{array}{c}\text { Total thickness } \\
{[\mathrm{mm}]}\end{array}$ & $\begin{array}{c}\text { Vol. fraction of } \\
\text { AlN composite } \\
{[\%]}\end{array}$ & $\begin{array}{l}\text { *Density } \\
{\left[\mathrm{g} / \mathrm{cm}^{3}\right]}\end{array}$ & $\begin{array}{c}* \text { Specific heat } \\
{[\mathrm{J} / \mathrm{kg} \cdot \mathrm{K}]}\end{array}$ & $\begin{array}{c}\text { Thermal diffusivity } \\
{\left[\mathrm{mm}^{2} / \mathrm{s}\right]}\end{array}$ & $\begin{array}{c}\text { Thermal } \\
\text { conductivity } \\
{[\mathrm{W} / \mathrm{m} \cdot \mathrm{K}]}\end{array}$ \\
\hline 0 & 2.020 & 0 & 2.70 & 896 & 65.44 & 158.3 \\
\hline 39 & 2.059 & 1.89 & 2.69 & 893 & 49.64 & 119.3 \\
\hline 53 & 2.073 & 2.56 & 2.69 & 892 & 47.55 & 114.1 \\
\hline 69 & 2.089 & 3.30 & 2.68 & 891 & 46.22 & 110.6 \\
\hline 119 & 2.139 & 5.56 & 2.67 & 888 & 40.36 & 95.8 \\
\hline 129 & 2.149 & 6.00 & 2.67 & 887 & 33.59 & 79.6 \\
\hline 163 & 2.183 & 7.47 & 2.66 & 885 & 30.71 & 72.4 \\
\hline
\end{tabular}

*Calculated value from rule of mixture using AlN composites and Al6061 substrates.

지의 경계면도 포논의 진행을 산란시키기 때문에 열전도 특 성에 악영향을 미칠 것으로 예측된다.

표 1은 본 연구에 사용된 Al6061기판과 $\mathrm{AlN}$ 복합재료 및 에폭시수지 각각에 대한 밀도, 비열, 열확산도 및 열전도도이 다. 표 2는 Al6061기판에 AlN 복합재료 후막을 서로 다른 두 께로 형성시킨 2층 층상재료에 대해 식 (1)을 사용해 열전도 도를 계산하는 과정과 관련된 자료를 나타낸다. AlN 복합재 료 후막의 두께가 $0 \mu \mathrm{m}$ 인 경우는 $\mathrm{Al}$ 기판에 대한 것으로, 표 1 에서 두께가 $2.02 \mathrm{~mm}$ 인 Al6061기판의 값과 같다. 두께가 $2.02 \mathrm{~mm}$ 인 Al6061기판에 $53 \mu \mathrm{m}$ 두께의 $\mathrm{AlN}$ 복합재료 후막 을 형성시켜 제조한 시편의 경우, 전체두께가 $2,073 \mu \mathrm{m}$ 인 2 층 층상재료에서 $\mathrm{AlN}$ 복합재로 후막의 부피분율(vol. fraction of AlN composite, $\mathrm{f}_{\mathrm{L}}$ )은 $2.56 \%$ 로 계산된다. 2 층 층상 재료의 열전도도의 계산을 위해, 2 층 단면구조를 갖는 층상 재료의 밀도와 비열을 표 1 의 값들을 혼합법칙에 적용시켜 계산하였다. $\mathrm{AlN}$ 복합재료 후막의 두께가 $53 \mu \mathrm{m}$ 인 2층 층상 재료의 경우, 밀도와 비열은 각각 $2.69 \mathrm{~g} / \mathrm{cm}^{3}$ 와 $892 \mathrm{~J} / \mathrm{kg} \cdot \mathrm{K}$ 로 나타났다.

AlN 복합재료 후막의 두께가 $53 \mu \mathrm{m}$ 인 2층 복합재료의 열 전도도 $\mathrm{k}_{\mathrm{c}}$ 는 식 (1)에서 $\mathrm{k}_{\mathrm{c}}=\alpha \times \rho \times \mathrm{C}_{\mathrm{p}}$ 로 표시되며, 표 2에 나 타낸 각 시편에 대한 열확산계수 $\alpha, 2$ 층 층상재료의 밀도 $\rho$ 및 비열 $\mathrm{C}_{\mathrm{p}}$ 을 대입해서 구했다. 즉, 두께가 $53 \mu \mathrm{m}$ 인 2층 층상 재료의 열전도도는 $47.55 \mathrm{~mm}^{2} / \mathrm{s} \mathrm{x} 2.69 \mathrm{~g} / \mathrm{cm}^{3} \times 892 \mathrm{~J} / \mathrm{kg} \cdot \mathrm{K}=$ $114.1 \mathrm{~W} / \mathrm{m} \cdot \mathrm{K}$ 로 나타난다. 동일한 방법으로 표 2에 나타낸, 서로 다른 두께의 AlN 복합재료 후막을 갖는 2 층 층상재료에 대한 값들도 구했다.

그림 4는 표 2의 결과를 사용해서, $\mathrm{AlN}$ 복합재료 후막의 두께 변화에 대한 2 층 층상재료의 열확산도와 열전도도의 변 화를 그래프로 나타낸 것이다. AlN 복합재료 후막의 두께가 증가할수록 2 층 층상재료 시편의 열확산도와 열전도도가 감

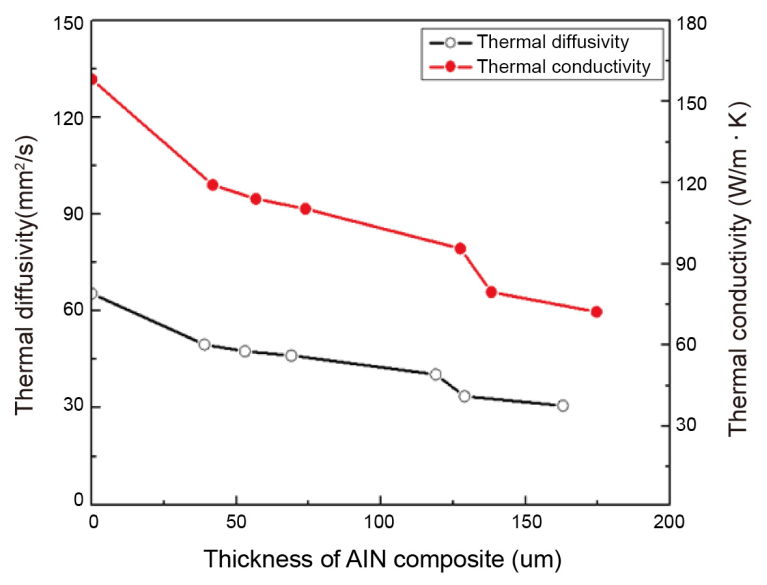

Fig. 4. Thermal properties of two-layered materials as a function of AlN-composite thickness.

소하였다. AlN 복합재료 후막의 두께가 $53 \mu \mathrm{m}$ 에서 $163 \mu \mathrm{m}$ 으로 증가하면 2층 층상재료의 열확산도와 열전도도는 각각 $47.55 \mathrm{~mm}^{2} / \mathrm{s}$ 와 $114.1 \mathrm{~W} / \mathrm{m} \cdot \mathrm{K}$ 에서 각각 $30.71 \mathrm{~mm}^{2} / \mathrm{s}$ 와 72.4 $\mathrm{W} / \mathrm{m} \cdot \mathrm{K}$ 로 감소했다. $\mathrm{AlN}$ 복합재료 후막의 두께가 증가함에 따라 2 층 층상재료의 열확산도와 열전도도가 감소하는 이유 는, $\mathrm{Al}$ 기판에 비해 AlN 복합재료 후막의 열확산도와 열전도 도가 낮기 때문이다. 따라서, 본 연구에서는 AlN 복합재료 후 막에 대한 특성평가를 한 후, 2층 층상재료의 두께 방향에 대 한 열전도 특성을 기존의 이론들과 비교하고 상세하게 고찰 하였다.

\section{4. 고 찰}

$\mathrm{Al}$ 기판에 $\mathrm{AlN}$ 복합재료 후막이 코팅된 2층 층상재료의 열 전도 특성을 평가하고 분석하기 위해, 본 연구에서 측정한 열 전도도를 식 (2)와 (3)의 열전도 관련 이론과 비교하였다. 표 1 에서 보듯이 $\mathrm{AlN}$ 복합재료 후막의 열전도도 $\left(\mathrm{k}_{\mathrm{L}}\right)$ 는 $0.6 \mathrm{~W} / \mathrm{m}$ 


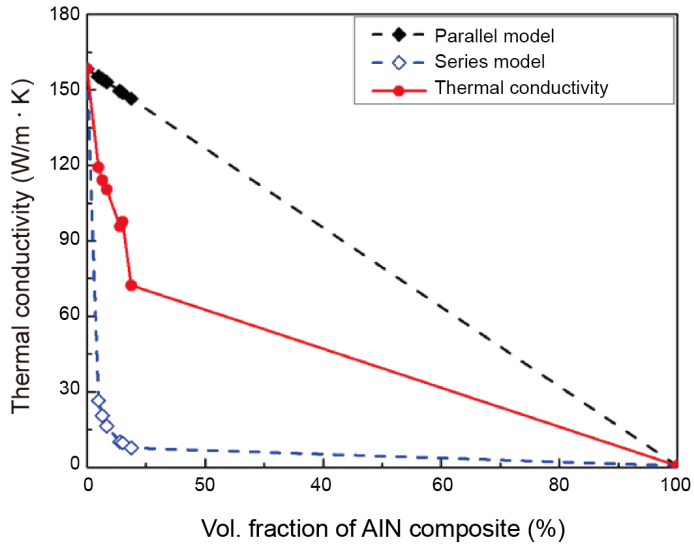

Fig. 5. Thermal conductivity of two-layered materials compared with the results from conventional models as a function of AlN-composite volume fraction.

$\cdot \mathrm{K}$ 이며, $\mathrm{AlN}$ 복합재료 후막의 부피분율 $\left(\mathrm{f}_{\mathrm{L}}\right)$ 은 표 2에 나타낸 바와 같다. 그림 3 의 SEM 사진은 AlN 복합재료 후막의 열전 도도가 $0.6 \mathrm{~W} / \mathrm{m} \cdot \mathrm{K}$ 로 낮게 나타나는 이유를 정성적으로 설명 한다. 즉, 열전도 특성이 우수한 AlN입자가 열전도도가 0.2 $\mathrm{W} / \mathrm{m}$ 로 낮은 에폭시 레진계 폴리머에 고립된(isolated) 분포 를 가지며, 동시에 AlN 복합재료의 미세조직은 열전도 특성 이 아주 불량한 수많은 기공들을 포함하고 있기 때문이다.

그림 5는 $\mathrm{Al}$ 기판과 $\mathrm{AlN}$ 복합재료 후막의 열전도도가 각각 $158.3 \mathrm{~W} / \mathrm{m} \cdot \mathrm{K}$ 와 $0.6 \mathrm{~W} / \mathrm{m} \cdot \mathrm{K}$ 인 결과를 사용해서, $\mathrm{AlN}$ 복합재 료의 부피분율에 따른 열전도도 변화를 나타낸다. 실선으로 표시한 결과는 그림 4 의 실험값이며, 점선으로 표시한 2 개의 결과는 표 1 과 표 2 의 값들을 병렬모델인 식 (2)와 직렬모델 인 식 (3)에 적용시켜 계산한 값이다. 두께 방향으로 측정한 열전도도는 다층 층상재료의 열전도도 관련 모델인 병렬모 델과 직렬모델로 계산한 결과와 큰 차이를 보인다. 즉, $\mathrm{Al}$ 기 판에 $\mathrm{AlN}$ 복합재료 후막을 코팅한 2층 단면구조 형상을 갖는 시편의 두께 방향으로 측정한 열전도도는 직렬모델을 적용 해 계산한 값과 비슷할 것으로 예상했지만, 오히려 병렬모델 과 직렬모델로 계산한 값의 사이에 위치하는 특별한 현상이 나타났다. 측정한 열전도도가 기존의 모델을 따르지 않는 이 유는, 그림 3에서 보듯이 AIN 복합재료 후막에는 수많은 기 공들이 존재하고, $\mathrm{AlN}$ 입자와 에폭시수지 사이에 입계 (boundary)가 존재해서, 이들이 포논의 진행을 방해하는 산 란 원(scattering source)로 작용하기 때문이다 [14,15]. 즉, 2 층 층상재료의 열전도 특성에서, 열전도 특성에 미치는 $\mathrm{AlN}$ 복합재료 후막과 $\mathrm{Al}$ 기판이 이루는 계면(interface)의 효과가 $\mathrm{AlN}$ 복합재료 후막에 존재하는 기공들과 입계의 효과에 비

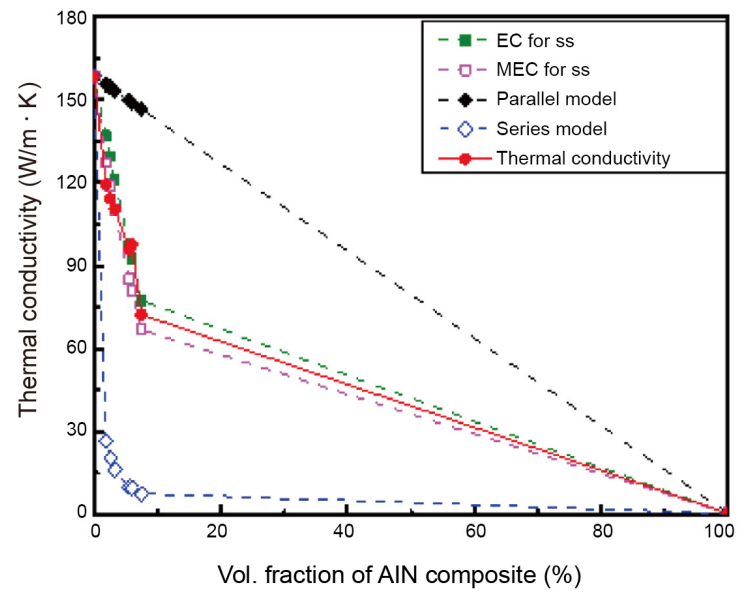

(a)

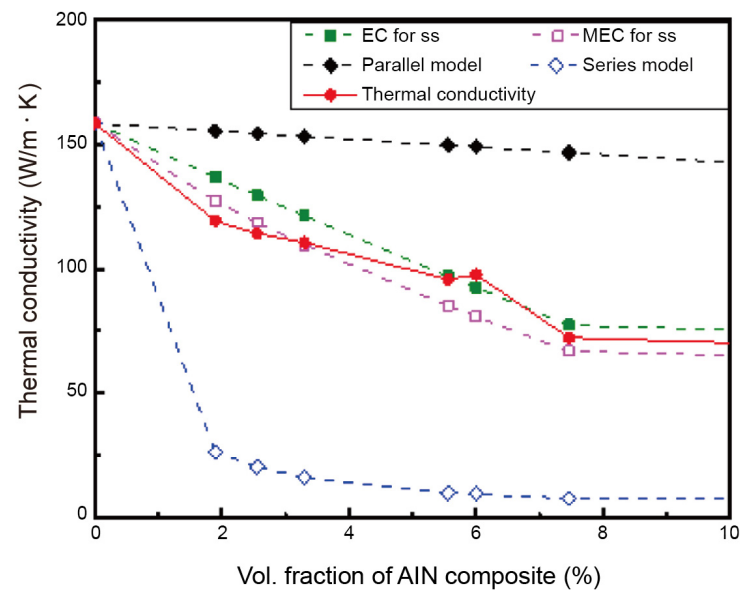

(b)

Fig. 6. Thermal conductivity of two-layered materials compared with the results from solid solution related models as a function of AlN-composite volume fraction: (a) for full range of AlN composite and (b) for low volume fraction of AlN composite. [EC for SS and MEC for SS are related to the electrical conductivity and modified electrical conductivity for solid solution, respectively].

해 크지 않기 때문으로 판단된다. 그림 5의 결과로 부터, 본 연구에서 사용된 2층 층상재료에서 두께 방향의 열전도도는 기존의 모델로 설명하기는 어렵다고 판단된다.

그림 3에서 보듯이, AlN 복합재료의 미세조직은 폴리머 기지(matrix)에 수많은 AIN 입자들이 분산되어 존재하고, $\mathrm{AlN}$ 입자와 폴리머 기지의 경계에는 미세한 기공들이 존재 한다. 그림 3 의 미세조직을 기초로 해서 2 층 층상재료의 열전 도도에 미치는 기공들의 영향에 대한 다양한 열전도 모델을 고려하였다. 그림 6 은 2 층 층상재료의 두께 방향으로 측정한 열전도도 변화를 설명하기 위해 새로운 모델들을 적용시켜 계산한 값들을 추가로 나타냈다. 그림 6(a)는 $\mathrm{AlN}$ 복합재료 


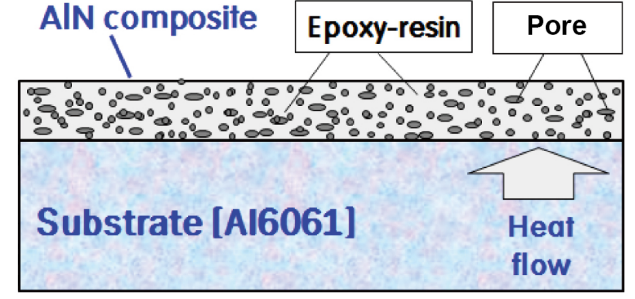

Fig. 7. Schematic model of two-layered material in view point of thermal conductivity along the thickness direction.

후막의 부피분율이 $0 \%$ 에서 $100 \%$ 까지의 범위에서 2 층 층상 재료의 열전도도 변화를 나타낸다. 그림 6에서 실선은 측정 한 열전도도를 나타내며, 측정값은 2성분계 고용체(solid solution, $\mathrm{SS})$ 의 전기전도도(EC for $\mathrm{SS})$ 모델과 고용체에 대 한 변형된 전기전도도(MEC for SS) 모델로부터 계산한 값과 비슷하게 나타났다 $[16,17]$. 즉, 본 연구에 사용된 2층 층상재 료 시편의 열전도도는 종래의 병렬연결 모델과 직렬연결 모 델로는 설명이 어렵지만, 고용체에서 적용되는 다른 모델로 는 설명이 가능함을 의미한다.

고용체에서 전기전도도(electrical conductivity, EC for SS) 모델은 다음과 같이 표시되며[16];

$$
k_{E C}=k_{m} f_{m}+k_{L} f_{L}+A\left(f_{m} f_{L}\right)=k_{c o m p}(P)+A\left(f_{m} f_{L}\right)
$$

고용체에서 변형된 전기전도도(modified electrical conductivity, MEC for SS) 모델은 다음과 같이 표시된다 [17].

$$
\begin{aligned}
\mathrm{kMEC} & =k_{m} f_{m}+k_{L} f_{L}+B\left[f_{m} \ln \left(f_{m}\right)+f_{L} \ln \left(f_{L}\right)\right] \\
& =k_{c o m p}(P)+B\left[f_{m} \ln \left(f_{m}\right)+f_{L} \ln \left(f_{L}\right)\right]
\end{aligned}
$$

식 (4)와 (5)에서 $\mathrm{k}_{\mathrm{EC}}$ 와 $\mathrm{k}_{\mathrm{MEC}}$ 는 각각 고용체에 대한 전기전 도도 모델과 변형된 전기전도도 모델을 적용시켜 계산한 열전 도도이다. $\mathrm{f}_{\mathrm{m}}$ 과 $\mathrm{f}_{\mathrm{L}}$ 은 2 층 층상재료에서 각각 모재(matrix)인 기 판과 $\mathrm{AlN}$ 복합재료 후막의 부피분율을 나타낸다. $\mathrm{A}$ 와 $\mathrm{B}$ 는 고 용체의 특성에 따라 변화되는 상수로서, 그림 6 은 $\mathrm{A}=-10$ 이고 $\mathrm{B}=300$ 인 경우에 대한 결과를 나타낸 것이다.

그림 6(b)는 측정한 열전도도와 고용체 모델로 계산한 결 과를 비교하기 위해 그림 6(a)의 $\mathrm{AlN}$ 복합재료 후막의 부피 분율이 $10 \%$ 이하인 부분을 확대해서 나타낸 것이다. 그림 6(b)의 결과는, 유전체인 AlN 복합재료 후막이 전기적 도체 인 $\mathrm{Al}$ 기판에 코팅된 2층 층상재료의 경우, 두께 방향의 열전
도도는 기존의 열전도도 모델로는 설명이 어렵고, 오히려 새 로운 고용체 모델로 설명하는 것이 용이함을 의미한다. 그림 7 은 2 층 층상재료에서 두께방향으로 측정한 열전도도가 고 용체의 변형된 전기전도도 모델을 응용한 결과와 비슷한 값 을 나타내는 이유를 설명하기 위한 개념도이며, AlN 복합재 료에 존재하는 수많은 기공들이 계면보다 더 강하게 열전도 도 변화에 영향을 주기 때문이다.

복합재료 시편에 대한 열전도 특성을 연구하기 위해서는 재료의 전기전도와 열전도 기구에 대한 고려가 필요하다 [18]. 고체 금속의 경우 전기전도도는 대부분 전자에 의해 지 배되며, 열전도도는 전자와 포논에 의해 지배된다. 금속의 경 우, 열전도도에 기여하는 전자의 기여율은 $90 \mathrm{~K}$ 주변의 저온 에서는 $30 \%$ 정도로 작지만, 상온에서는 전자의 기여율과 포 논의 기여율은 대략 $65 \%$ 대 $35 \%$ 로 전자의 기여율이 증가한 다 [18,19]. 반면, $\mathrm{AlN}$ 복합재료 후막과 같은 유전체의 경우, 열전도도에 미치는 전자의 기여는 무시할 수 있기 때문에, 대 부분 포논의 기여 때문으로 볼 수 있다 [19]. 또한, 이종소재의 계면에는 다양한 결함들이 존재하기 때문에 [20-22], 금속 기 판에 유전체 후막이 코팅된 2 층 층상재료에 대한 본 연구에서 두께 방향의 열전도 특성이 고용체 모델을 따르는 이유는 다 음과 같다고 생각된다. 그림 7에서 보듯이, $\mathrm{AlN}$ 복합재료의 후막에는 열전도 특성이 불량한 수많은 미세한 기공들이 존 재하고, $\mathrm{AlN}$ 입자와 에폭시수지의 경계면 또한 열전달을 방해 하는 요소로 작용하기 때문에 $\mathrm{AlN}$ 복합재료와 $\mathrm{Al}$ 기판이 이 루는 계면의 효과는 상대적으로 작아졌기 때문이다.

\section{5. 결 론}

판상의 $\mathrm{Al}$ 기판에 $\mathrm{AlN}$ 함유 폴리머(AlN 복합재료) 후막을 코팅한 2층 층상재료 시편을 제조하고, 두께 방향에 대한 열 전도 특성을 연구하여 다음과 같은 결론을 얻었다.

1. Al기판에 AlN 복합재료 후막을 코팅시킨 2층 층상재료 시편의 경우, 실험적으로 측정한 두께 방향의 열전도도는 전 기저항의 병렬연결 모델과 직렬연결 모델로 계산한 값과는 큰 차이를 나타냈다.

2. 고용체에 대한 전기전도도와 변형된 전기전도도를 기술 하는 새로운 모델을 적용함으로써 2 층 층상재료 시편에 대한 두께 방향의 열전도 특성을 설명할 수 있었다. 이유는, AlN 복합재료 후막에는 $\mathrm{AlN}$ 입자의 주변에 방향성이 없는 수많 은 기공들과 $\mathrm{AlN}$ 입자와 에폭시수지의 경계면이 존재하기 때 문이다. 
3. 판상의 금속 기판에 포논의 이동을 저해하는 수많은 결 함들을 함유한 유전체 복합재료 후막이 코팅된 2층 층상재료 시편의 경우, 두께 방향의 열전도 특성의 연구에는 고용체의 전기전도도 모델과 변형된 전기전도도 모델을 적용하는 것 도 필요하다.

\section{감사의 글}

본 연구는 재료연구소(KIMS) 주요사업의 연구비 지원과, 2016년도 산업통상자원부의 재원으로 한국에너지기술평가 원(KETEP)의 에너지인력양성사업으로 지원받아 수행한 성 과입니다. (No. 20164010201000).

\section{REFERENCES}

1. W. Suh, H. S. Jung, Y. H. Lee, Y. H. Kim, and S. H. Choa, J. Microelectron. Packag. Soc. 21, 7 (2014).

2. Y. J. Heo, H. T. Kim, K. J. Kim, S. Nahm, Y. J. Yoon, and J. Kim, Appl. Therm. Eng. 50, 799 (2013).

3. S. C. Cho, S. H, Ko, H. S. Kim, J. P. Ahn, and J. H. Han, Korean J. Met. Mater. 53, 911 (2015).

4. W. Feng, L. Zhang, Y. Liu, X. Li, L. Cheng, and B. Chen, Mater. Sci. Eng. A 626, 500 (2015).

5. S. M. Na, S. I. Go, and S. J. Lee, J. Kor. Ceram. Soc. 48, 368 (2011).

6. B. Weidenfeller and S. Kirchberg, Compos. Part B 92, 133 (2016).

7. G. Kim, K. M. Jung, J. T. Moon, and J. H. Lee, J.
Microelectron. Packag. Soc. 21, 51 (2014).

8. J. W. Roh, S. Y. Jang, J. Kang, S. Lee, J. S. Noh, J. Park, and W. Lee, Korean. J. Met. Mater. 48, 175 (2010).

9. M. Abdel-Rahman, S. Ilahi, M. F. Zia, M. Debbar, N. Yacoubi, and B. Ilahi, Infrared Phys. Technol. 71, 127 (2015).

10. J .G. Kim, D. H. Bae, B. D. Hahn, and Y. R. Cho, Compos. Part B 110, 1 (2016).

11. H. J. Ratzer-Scheibe, U. Schulz, and T. Krell, Surf. Coat. Technol. 200, 5636 (2006).

12. C. J. H. Helmereich, R. Corbin, and S. M. McDeavitt, J. Nucl. Mater. 446, 100 (2014).

13. M. V. Krishnaiah, G. Seenivasan, P. S. Murti, and C. K. Mathews, J. Alloy. Compd. 353, 315 (2003).

14. A. Majumdar and P. Reddy, Appl. Phys. Lett. 84, 4768 (2004).

15. K. E. Goodson and M. I. Flik, ASME J. Heat Transfer 115, 17 (1993).

16. C. R. Barrett, W. D. Nix, and A. S. Tetelman, The Principles of Engineering Materials, Revised Printing, pp.391-396, Prentice Hall, Inc. New Jersey (1973).

17. D. A. Porter and K. E. Easterling, Phase Transformations in Metals and Alloys, 1st ed., pp.13-15, Van Norstrand Reinhold Company, New York (1981).

18. P. E. Hopkins, M. Ding, and J. Poon, J. Appl. Phys. 111, 103533 (2012).

19. C. L. Choy, K. W. Tong, H. K. Wong, and W. P. Leung, J. Appl. Phys. 70, 4919 (1991).

20. J. H. Kim, B. O. Lee, J. S. Cheon, and S. H. Kim, Korean J. Met. Mater. 54, 855 (2016).

21. M. M. Hoseini-Athar and B. Yolaminejad, Met. Mater. Int. 22, 670 (2016).

22. J. S. Kim, J. Park, K. S. Lee, S. Lee, and Y. W. Chang, Met. Mater. Int. 22, 771 (2016). 